\title{
Enhancing the Role of Early Childhood Education Institution in an Effort to Grow Ecoliteracy
}

\author{
Mirza Desfandi $^{\mathrm{a}, \mathrm{b}}$, Enok Maryani ${ }^{\mathrm{c}}$, Disman $^{\mathrm{d}}$

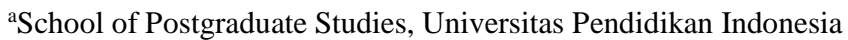 \\ bepartment of Geography Education, Universitas Syiah Kuala \\ ${ }^{\mathrm{c}}$ Department of Geography Education, Universitas Pendidikan Indonesia \\ ${ }^{\mathrm{d}}$ Department of Economy Education, Universitas Pendidikan Indonesia \\ Corresponding e-mail: $\underline{\text { mirza_des@ } @ \text { unsyiah.ac.id }}$
}

\begin{abstract}
Eco literacy is an effort to embody sustainable community that is community who organize their life by considering the importance of life environment protection and preservation. This article aim to describe how important that Eco literacy should be possessed by each individual today and how the effort that should be done by early childhood education institution in an effort to grow Eco literacy in individual from early age. The method which is used is bibliography study. From result of explanation, it can be stated that Eco literacy should be implanted to each individual from early age, because early childhood is period of intellectual development and period of behavior shaping. In early childhood various stimulus which are given will become foundation for a child in his/her future life. Because of that, early childhood education institution should be play a role in embodying individual who has ecological literacy (Eco literacy) by implementing comprehensive effort, from developing environmental concept policy, implementing environmental based curriculum, building eco-friendly school culture and managing eco-friendly infrastructure.
\end{abstract}

Keywords: $\quad$ early childhood education institution, Eco literacy

\section{INTRODUCTION}

In a very general term, environment problem is defined as side effect of artificial environment made by people in nature (Baltaci et al, 2015:139). One thing being offered to overcome environment problem is by creating community of people who arrange their life by considering the importance of life environment protection and preservation which is resourced from what is called by Capra as Eco literacy (Keraf, 2014:126).

Ecological literacy or abbreviated as Eco literacy means literate toward condition and knowledge about life relatedness in earth or in the other word, capable to understand the relatedness base between human and nature (Martin (2008:35). According to Barnes (2013:2), ecology literacy focus on developing our understanding of interconnection between earth natural system and human system. Ecology literacy try to introduce and renew people understanding about the importance of global ecology awareness, in order to create the balance between people needs and earth capacity to sustain it (Pitman \& Daniels, 2016:2).

Building Eco literacy in each individual should be started from early age, because the period of early childhood is critical period and play important role in individual life. Early childhood is period of intellectual development and period of behavior shaping. In early childhood, various stimulus which are given will become foundation for a child in his/her future life. Because of that, meaningful experiences should be provided to children included regarding attitude and activity of environment cared, in order to shape children who have ecology literacy. This need the support from parent and their environment included education institution. Ozsoy et 
al. (2012) examines the effect of Eco School on the environmental literacy level of primary school students in Turkey, then in Barnes (2013) article explained how efforts to improve the level of Eco literacy students at all levels of education. This article will explain how important of Eco literacy should be possessed by all individuals and how the effort which can be done by early childhood education institution in order to build students' Eco literacy.

\section{METHOD}

Artkel is a literature review based on the book and scientific journals in order to provide a comprehensive description of the efforts to enhance the role of early childhood education institutions in building Eco literacy.

\section{DISCUSSION}

Eco literacy is term which first used by David W. Orr and Fritjof Capra in 1990's, to introduce new value for welfare of earth inhabitants and their ecosystem into education practice (Keraf, 2013:55).

\subsection{The Importance of Eco literacy in Effort to Realize Sustainable Community}

As new paradigm, Eco literacy initiate the movement as effort to care about environment and aimed to increase community's ecology awareness. Eco literacy try to introduce and renew their understanding about the importance of global ecology awareness, in order to create the balance between community needs and earth capability to sustain it. Because of that, Eco literacy according to Orr (2004) means the condition of people who had been aware of the importance of life environment. In short, Eco literacy describe the awareness of the importance of life environment. Capra (2007:2) defined ecology literacy as "understanding the basic principles of ecology and capable to realize it in daily life." Then ecology literacy is defines by Berkowitz, Ford \& Brewer (2005:228) as "ability to use ecology understanding, thinking and get used to think for life, enjoy or learn about environment."

Eco literacy is focused on developing our understanding about interconnection between earth natural system and human system (Barnes, 2013:2). Eco literacy is very important in the world today, in which earth inhabitants are confronted with the increase of environment challenge included climate change, limited resources, and environment related diseases. Marchildon (2012:4) suggested that Eco literacy is very important because:

- Alienation from nature is contributing to environmental problems

- We now are at a critical point with many issues, such as climate change, biodiversity, deforestation.

- Eco literacy is imperative for political and business leaders, as well as in all levels of educational system.

Based on opinion above, ecological literacy is very important in life on earth which is critical today. We now are at critical point with many issues problems, such as climate change, biodiversity, and deforestation. If we do not response to this problem, it will contribute to environment problem which is worse. Therefore, according to Keraf (2014:129) Eco literacy is very important for all, such as politician and businessman, and in all education system level.

Awareness should become a system which can be started from individual behavior to arrangement of politic, economy and education system. Practically, it can started from basic needs consumption, energy consumption, technology usage and household equipment, house maintenance, building and office design, agriculture, industry and business development, and office management. There are six main competence from ecological literacy according to Bell, 1997; Berkowitz, Ford, \& Brewer, 2005; Curthoys \& Cuthberston, 2002; Orr, 1992; Puk \& Behm, 2003, namely:

- Natural history skills that foster familiarity with community members and life sustaining processes of one's own bioregion, as well as the ability to interpret ecosystem health.

- Awareness, sensitivity and compassion toward other life forms that engenders kinship with natural systems.

- Knowledge of ecological laws and patterns that inform how actions might affect natural systems.

- Critical thinking skills that illuminate connections between actions, the health of natural systems and community wellbeing.

- A sense of responsibility, willingness and practical skills that enable engagement in creative and socially just actions addressing sustainability issues.

- Understanding of cultural values and worldviews that affect human perceptions and relationships with nature. 
Based on six competences above, it can be known that ecology learning is basic thing in instilling ecological literacy and to realize sustainable community, that is community who arrange their life by considering the importance of protection and preservation of life environment. Goleman (2010:39) asserted that ecological intelligence integrate cognitive skill and empathy toward all forms of life. Social and emotional intelligence is built on ability to see from another point of view, feel what other people felt and show our care. Ecological intelligence broaden the capacity of all natural system.

Based on explanation above, it can be stated that the depth ecological awareness is spiritual and religious awareness so Eco literacy is a concept which should be possessed by community at large included children in order that they understand about the importance to maintain environment preservation, responsible and play active role as world citizen, and aware that the balance of natural environment is also part of maintaining the place of human life survival itself.

\subsection{The Role of Early Childhood Education Institution in Effort to Build Child's Eco literacy}

By introducing the surrounding environment to children, they can develop a scholarship inter discipline thought by thinking critically, creatively and knowledge literate to familiar with environment where they live. So, it is hoped that child's attitude and love toward their environment will be built so there is effort to keep its preservation (Stone \& Barlow, 2005). Therefore in education field, Eco literacy should become main focus in education curriculum as effort to face serious challenge of environment problem in the future (Puk \& Behm, 2003:217). The life survival which is sustainable and the existence of harmonious relation between nature and human activity within it become not separated. Thus, ecological awareness should be instilled then Eco literacy concept is done continually in order to become habituation.

In order to realize Eco literacy behavior, various ways need to be done to equipment children in school, particularly to give understanding and various practical skills about Eco literacy bases such as experience with surrounding world, how nature sustain life, to maintain community health, to find out about the cause and effect or foods we eat every day, and to know well the places where we live, work and learn, etc. To build child's Eco literacy, early childhood education institution need to do comprehensive effort, from developing environment policy, environment based curriculum implementation, build eco-friendly school culture and infrastructure management by eco-friendly.

School policy become foundation for education institution and its citizens in arrangement of planning and budget as well as goal direction of education institution. In development of school policy regarding environment, some things which can be done by early childhood education institution among others are: (1) School plan about activity and budget contain the effort of life environment protection and management; (2) Curriculum structure contain material concerning policy of life environment protection and management; and (3) Vision, mission and aim of education institution contain policy of life environment protection and management. Therefore, vision, mission and aim of education institution should become foundation for all components of education institution in behaving and acting which in accord with vision, mission and aim which had been established by institution.

In implementation of environmental based curriculum, early childhood education institution must strive for (1) Educators apply learning approaches, strategies, methods, and techniques which involve students in learning actively; (2) Developing local issue and/or global issue as learning material of environment and also relating conceptual and procedural knowledge in solving environmental problems, and the application in the daily life; and (3) Inviting parents and community as participants in environmental learning program. Through implementation of environmental based curriculum, children do not only gain knowledge and learning, but also they have attitude and behavior to preserve the environment and also have skill which is useful in managing environment. It is hoped with Eco literacy based learning, children will be aware of the importance in preserving environment.

Center for Eco literacy (2013) can give various directions which can be conducted in learning to give students' understanding about Eco literacy for survival so students are able to understand and practice it in different environment and context. Such directions are follows:

- Developing empathy for all forms of life, this practice can push students to strengthen caring towards other forms of life.

- Understanding the continuity of other community network, this practice can be emerged from the knowledge that living things 
have relations with each other. The life quality of community network can determine collective ability of living things to survive and develop.

- Minimalizing the bad effect towards environment (reduce), helping students in realizing that many impacts which are caused human acts towards each other and environment. Because of human acts in time, space, and size, it will be difficult if do not understand completely.

- $\quad$ Anticipating the undesired impact (preventive), it can make students learn to predict the possibility of behavior involvement.

- Understanding how nature can sustain life, it is very important for students to change their habit and also community habit for the next generation and other form of life.

Then, the institution of early childhood education must be able to build school culture which preserve environment. Several things that must be done, among others: (1) Involving all educational institutions in preserving and maintaining building and environment, as in the mutual cooperation and plants conservation by involving children directly; and (2) Making use area and facilities in accordance with rules in preserving and managing environment, among others with park and plantation maintenance, and trash management. Clean and Healthy Life Behavior (CHLF) is an embodiment of culture which preserve environment. CHLF is an effort in creating individual/group can prevent disease independently, improving their health and active in creating healthy school environment (Proverawati \& Rahmawati, 2012:22). So, clean and health school environment is not only felt comfortable for school community, but also can maintain and improve students' health.

In building school culture, the role of principal is very crucial. Principal has to be a role model and motivator for their subordinates and students in doing various activities. Besides principal leadership, other people who have crucial role in building school culture are teachers. The role of teacher is not only in teaching and learning activities at school, but also teachers must have a role as students' guidance in activities outside school, including in school environment management. As for discipline aspect, teacher can be a role model for children, what is done by teacher can be a model for children to follow. Because of that, at school, teacher must give a good example towards students in many things, including in maintaining and preserving environment. Through school culture building which preserve environment, so, it is expected that educational institution of early childhood can be a place to learn about the proper values of preserving and managing environment for school community and also wider community.

The management of school infrastructures has a function in organizing and maintaining educational infrastructures, so, it can give contribution optimally and also can give contribution towards the process of education. The management of infrastructures which preserve environment which can be conducted by early childhood institution among others: (1) The availability of infrastructures for handling environment problems, such as: clean water, trash can, hygienic water closet, park, and open area; (2) Space which has natural window and ventilation; and (3) Using electricity, water and stationery efficiently. The availability of school infrastructures which preserve environment and also management of school infrastructures continuously is hoped can create comfortable school environment and also the availability of adequate learning facilities.

\section{CONCLUSIONS}

Based on the discussion above, it can be concluded that: (1) in an effort to embody sustainable community, namely, community which organize their life by considering the importance of environment protection and preservation, it is needed individual who has Eco literacy. The implantation of Eco literacy towards individual must be implanted since early childhood, because early childhood is a critical period and has an important role in individual life. (2) In implanting Eco literacy towards individual, it is needed a comprehensive effort which must be conducted by early childhood institution, which includes: (a) developing environmental concept policy, (b) implementation of environmental based curriculum, (c) building ecofriendly school culture and (d) the management of eco-friendly infrastructures.

Based on conclusion above, it can be recommended that Eco literacy must be possessed by every individual since early childhood. In implanting Eco literacy, the role of educational institutional is very crucial, in which the principals and teachers' awareness, willingness and commitment are required in implementing the four components above so it is not only can grow children Eco literacy but also can embody children who are not only physically health but also mentally health. 


\section{REFERENCES}

Baltaci, F., Yirik, S., Sargi, S.A, \& Yumusak, A. (2015). From the Ecocentric and Anthropocentric Perspectives, a Survey of Future Tourism Entrepreneurs' Attitudes toward Environmental Issues: Sample of Akdeniz University. International Journal of Humanities and Social Science, Vol. 5, No. 1; January 2015, 139-143.

Barnes, J.C. (2013). Awareness to Action: The Journey toward a Deeper Ecological Literacy. Journal of Sustainability Education, Vol. 5, May 2013.

Bell, A. (1997). Nature Study from a Learner's Perspective. Canadian Journal of Environmental Education, 2, 132-144.

Berkowitz, A.R., Ford, M.E. \& Brewer, C.A. (2005). A Framework for Integrating Ecological Literacy, Civics Literacy and Environmental Citizenship in Environmental Education. In E.A. Johnson \& M.J. Mappin (Eds.), Environmental Education and Advocacy: Perspectives of Ecology and Education (227-266). Cambridge: Cambridge University Press.

Capra, F. (2007). Sustainable Living, Ecological Literacy, and the Breath of Life. Canadian Journal of Environmental Education, 12, 2007

Center for Eco literacy. (2013). Discover: Competencies. Center for Eco literacy, Berkeley, California, USA. [Online]. Retrieved November 18, 2014, from http://www.ecoliteracy.org/taxonomy/ term/84.

Curthoys, L.P \& Cuthbertson, B. (2002). Listening to the Landscape: Interpretive Planning for Ecological Literacy. Canadian Journal of Environmental Education, 7(2), Spring 2002

Goleman, D. (2010). Ecological Intelligence: Mengungkap Rahasia di Balik Produk-Produk yang Kita Beli. (Translate). Jakarta: PT. Gramedia Pustaka Utama.

Keraf, A. S. (2013). Risalah Tentang Kehidupan: Sebuah Telaah Filsafat Lingkungan Hidup. Jurnal Lingkungan Indonesia. Vol. 1, No. 1 (3-11). - (2014). Filsafat Lingkungan Hidup, Alam Sebagai Sebuah Sistem Kehidupan. Yogyakarta: Kanisius.

Marchildon, S. (2012). The Role of Ecological Literacy in the Shift to a More Sustainable Future. Article, Workshop on the Implementation of Article 6 of the Convention in Least Developed Countries, in Bonn, Germany, June 19, 2012.

Martin, P. (2008). Teacher Qualification Guidelines, Ecological Literacy and Outdoor Education. Australian Journal of Outdoor Education, 12(2), 3238, 2008.

1.1 Orr, D.W. (1992). Ecological Literacy: Education and the Transition to a Postmodern World. Albany, New York: SUNY Press.

(2004). Ecological Design Intelligence. [Online]. Retrieved November 18, 2014, from www.ecoliteracy.org/.../ecological-designintelligence. November 18, 2014.
Ozsoy, S., Ertepinar, H \& Saglam, N. (2012). Can Eco-Schools Improve Elementary School Students' Environmental Literacy Levels? Asia-Pacific Forum on Science Learning and Teaching, Vol. 13 Issue 2/December 2012.

Pitman, S.D \& Daniels, C.B. (2016). Quantifying Ecological Literacy in an Adult Western Community: The Development and Application of a New Assessment Tool and Community Standard. PLOS ONE 11(3): e0150648. doi:10.1371/journal.pone.0150648. March 3, 2016.

Proverawati, A \& Rahmawati, E. (2012). Perilaku Hidup Bersih dan Sehat (PHBS). Yogyakarta: Nuha Medika.

Puk, T.G. \& Behm, D. (2003). The Diluted Curriculum: The Role of Government in Developing Ecological Literacy as the First Imperative in Ontario Secondary Schools. Canadian Journal of Environmental Education, 8, 217-232.

Stone, M.K \& Barlow, Z (2005). Ecological Literacy: Educating Our Children for a Sustainable World. San Francisco: Sierra Club Books. 